\title{
Expression of calpastatin and myostatin genes associated with lamb meat quality
}

\author{
A. Bagatoli ${ }^{1}$, E. Gasparino ${ }^{1}$, M.A.M. Soares ${ }^{2}$, R.M. Amaral ${ }^{1}$, \\ F.A.F. Macedo ${ }^{1}$, D.M. Voltolini ${ }^{1}$ and A.P. Del Vesco ${ }^{1}$ \\ ${ }^{1}$ Universidade Estadual de Maringá, Departamento de Zootecnia, \\ Maringá, PR, Brasil \\ ${ }^{2}$ Departamento de Genética, Universidade Federal Rural do Rio de Janeiro, \\ Seropédica, RJ, Brasil \\ Corresponding author: E. Gasparino \\ E-mail: egasparino@uem.br
}

Genet. Mol. Res. 12 (4): 6168-6175 (2013)

Received October 11, 2012

Accepted May 9, 2013

Published December 4, 2013

DOI http://dx.doi.org/10.4238/2013.December.4.3

\begin{abstract}
Calpastatin (CAST) is an endogenous calpain inhibitor and its main function is to modulate the proteolytic action of enzymes responsible for post-mortem myofibril deterioration. The myostatin gene (GDF-8) acts as a negative regulator of skeletal muscle growth. The expression of these two genes, as well as their interaction, affects the quality of the meat, especially the tenderness phenotype. We evaluated the genetic groups Santa Inês, 1/2 Dorper-Santa Inês and $1 / 2$ White Dorper-Santa Inês, slaughtered with $2.0 \mathrm{~mm}, 2.5 \mathrm{~mm}$ and $3.0 \mathrm{~mm}$ of fat thickness, comparing the levels of expression of the CAST and GDF-8 genes with the weight performance and carcass traits, especially the shear force values. We found significantly higher expression of myostatin and calpastatin in the Santa Inês genetic group. The $1 / 2$ Dorper-Santa Inês genetic group had the lowest expression of these genes when slaughtered with 2.0 and $2.5 \mathrm{~mm}$ of fat thickness. In conclusion, the Santa Inês breed had the lowest phenotype values for meat tenderness, and the $1 / 2$ Dorper-Santa Inês breed had the best performance for this characteristic. We suggest that high levels of the
\end{abstract}


expression of the CAST and GDF-8 genes are associated with lower values of lamb meat tenderness, and that tenderness is related to the stage of muscular growth and development.

Key words: Fat thickness; Gene expression; Tenderness

\section{INTRODUCTION}

For any animal species bred for human consumption, meat tenderness is one of the most important aspects for consumers. This characteristic is influenced by genetic and environmental factors. Therefore, some aspects can be considered in the animal prior to slaughter, such as age, sex and nutrition, as well as the post-mortem processes, such as maturation, carcass cooling, $\mathrm{pH}$ and cooking of the meat (Asghar and Pearson, 1980); all these factors have a positive or negative effect on tenderness. Another aspect, no less important than those mentioned above, is that of cellular processes, such as the actin-myosin binding complex which promotes muscle contraction by shortening the sarcomere and activating calpastatin, associated with increased rigidity, as well as the antagonistic processes provoked by the calpains that act in myofibril proteolysis resulting in greater tenderness (Soria and Corva, 2004).

After slaughter, biochemical transformations occur in the musculature, initiating a series of events that modify muscle tissue into actual meat, and in this phase, the tenderness trait may be essentially attributed to the structure and activity of the myofibril complex (Moody et al., 1970). As reviewed by Hopkins and Thompson (2002), the evidence suggests that meat tenderness is mainly attributed to $\mu$-calpain activity, which is a protease that deteriorates the myofibril proteins of the muscle during refrigerated storage. On the other hand, calpastatin activity is higher during the first $24 \mathrm{~h}$ in the post-mortem period, indicating that it is probably a primary regulator of $\mu$-calpain (Morgan et al., 1993), which requires low concentrations of calcium and is activated when $\mathrm{pH}$ decreases (Volpelli et al., 2004). Meats with high calpastatin activity in this period become less tender (Rubensam et al., 1998).

Like the calpastatin gene (CAST), the myostatin gene, also known as growth differentiation factor 8 (GDF8) is predominantly expressed in skeletal muscle, which has the function of controlling the proliferation of myoblasts and the formation of muscle fibers (Ciéslak et al., 2003), acting as a negative autocrine regulator (Du et al., 2007). A mutation in this gene can lead to reduced expression, such as in knockout animals that exhibit a threefold increase in their muscle mass, caused by hypertrophy of muscle fibers, or an overexpression that leads to hyperplasia of muscle cells (Lee and McPherron, 2001). Furthermore, myostatin can also act as an adipogenic regulator, where its gene deletion causes lesser fat build-up due to its direct action. Its activity can be inhibited by various proteins, such as follistatin (Guizoni et al., 2010).

Due to the characteristic action of these proteins on muscle fiber, some research groups have studied the genetic polymorphisms that could be associated with meat tenderness. For example, Morris et al. (2006) examined the genotypic effects of calpastatin (CAST) and calpain 1 (CAPN1) on the longissumus dorsi muscle in the bovine cross-breeds of Jersey and Limousin, and Angus and Hereford, and found significant differences in shear force between the genetic combinations. They showed that inferior meat tenderness was related to the combinations CAPN1 GG and CAST AG and greater tenderness to the combinations CAPN1 CC and CAST AA, with differences of $25.7 \pm 5.5$ and $15.2 \pm 4.8 \%$, respectively. 
As well as identifying genetic polymorphisms, determining gene expression levels active in the muscle can also help us to understand their interaction. Using the real-time PCR method, one can analyze the calpastatin and myostatin expression pattern, and the responses obtained can be used as tools to aid genetic improvement programs in those populations. The aim of this study was, therefore, to assess the expression of calpastatin and myostatin genes in the longissimus lumborum muscle through the use of real-time PCR and to associate such gene expressions with meat quality in pure lambs [Santa Inês (SI)] and cross-breeds [ $1 / 2$ Dorper-Santa Inês $(1 / 2 \mathrm{D}-\mathrm{SI})]$ and $1 / 2$ White Dorper-Santa Inês [ $1 / 2 \mathrm{WD}-\mathrm{SI})]$, considering three abdominal fat thicknesses for slaughter.

\section{MATERIAL AND METHODS}

The study included 36 uncastrated male lambs, weaned at 60 days, with twelve in each breed group: SI, $1 / 2 \mathrm{D}$-SI and $1 / 2 \mathrm{WD}$-SI. The animals were distributed in sheltered, individual pens, with suspended, slatted floor, and they received unlimited water throughout the experimental period and were fed complete pellet feed, formulated for a daily weight gain of $0.300 \mathrm{~kg}$ (NRC, 2007), supplied once a day, without restrictions, in such a way as to produce daily leftovers of approximately $10 \%$. The treatments were defined as fat thickness for slaughter of the lambs, at 2.0, 2.5 and $3.0 \mathrm{~mm}$, assessed by ultrasound scan, between the 12th and 13th ribs. The ultrasound scans and weighing were performed every seven days. The subcutaneous fat thickness (SFT) and longissimus lumborum muscle depth (LUMD) were measured with a Honda model HS-1500 VET, with a $50-\mathrm{mm}$ wide, linear multi-frequency transducer, used at a frequency of 7.5 MHz. The lambs were slaughtered when they attained the predetermined fat thickness, regardless of their weight.

Total RNA was extracted from the longissimus lumborum muscle of each animal, using the Trizol ${ }^{\circledR}$ reagent (Invitrogen, Carlsbad, CA, USA), at a proportion of $1 \mathrm{~mL} / 100$ $\mathrm{mg}$ tissue, in accordance with manufacturer recommendations. Quantification was done with a spectrophotometer at $260 \mathrm{~nm}$ and RNA integrity was assessed on a 1\% agarose gel, visualized under ultraviolet light. The cDNA was prepared using a SuperScrippt ${ }^{\mathrm{TM}}$ III First-Strand Synthesis Super Mix kit (Invitrogen Corporation, Brazil), as per manufacturer recommendations.

The primers used in the reactions were designed according to the CAST and GDF-8 gene sequences deposited at the website www.ncbi.nlm.nih.gov, with accession Nos. AY834770 and AB076403, respectively. The GADPH gene, which encodes the glyceraldehyde 3-phosphate dehydrogenase enzyme (AF022183) (Table 1), and the $\beta$-actin gene (AF035422) were tested as endogenous controls, with the former being chosen due to its greater efficiency in the reaction and less variation between treatments.

Table 1. Primer sequence, fragment annealing temperature for CAST, GDT-8 and GADPH, respectively.

\begin{tabular}{llcc}
\hline Gene & Primer & Annealing temperature $\left({ }^{\circ} \mathrm{C}\right)$ & Fragment $(\mathrm{bp})$ \\
\hline CAST & Forward: TGCCCTGGATCAACTTTCTG & 60 & 149 \\
& Reverse: GGTATTTAGGTGGGATGGTGTC & 60 & 86 \\
GDF-8 & Forward: ACCCATGAAAGACGGTACAAG & & 78 \\
& Reverse: CAATGCTCTGCCAAATACCAG & 60 & \\
GAPDH & Forward: CCAGGCAGAGAACGGGAAG & & \\
& Reverse: GCCTTCTCCATGGTAGTGAAG & & \\
\hline
\end{tabular}


SYBR GREEN (SYBR ${ }^{\circledR}$ GREEN PCR Master Mix - Applied Biosystems, USA) fluorescent compound was used for the real-time PCR reactions. For calculation of the expression values of the muscle tissue samples for, the $\Delta \mathrm{Ct}$ was calculated, given by the difference from the cycle threshold (of the exponential phase) of each sample and each gene and the $\mathrm{Ct}$ of the endogenous controls of the sample. All trials were performed in a final volume of $25 \mu \mathrm{L}$ and in duplicate. Finally, the specificity of the PCR products was checked by melting curve analysis after the qRT-PCR reaction.

Statistical analysis of the traits under investigation was conducted using the GLM procedure of SAS (SAS Institute Inc., 2002). Analysis of variance was performed considering a $5 \%$ level of significance, as per the model: $\mathrm{Y}_{\mathrm{ij}}=\mu+\mathrm{GR}_{\mathrm{i}}+\mathrm{EGSU}_{\mathrm{j}}+\mathrm{GR} \times \mathrm{EGSU}_{\mathrm{ij}}+\mathrm{e}_{\mathrm{ij}}$, where: $Y_{i j}=$ observation relative to breed group i, slaughtered with thickness $\mathrm{j}, \mu=$ general constant, $G R_{i}=$ effect of breed group i; where i $=1,2$ and $3, E G S U_{j}=$ effect of fat thickness at slaughter $\mathrm{j}$, where $\mathrm{j}=1,2$ and $3, G R \times E G S U_{i j}=$ effect of interaction between breed group and fat thickness at slaughter, and $E_{i j}=$ random error associated with each observation $Y_{i j}$. The UNIVARIATE procedure was used to verify normality of the gene residues under study (expressed as $\left.2^{-\Delta \mathrm{Ct}}\right)$. The averages were compared by the Tukey test $(\mathrm{P}<0.05)$.

\section{RESULTS}

Tables 2 and 3 show the average values \pm standard deviation of the weight performance of each genetic group and abdominal fat thickness. For the performance and carcass traits, the effect of interaction was not determined. Significant differences were found between the genetic groups in relation to weight of hot carcass, average daily weight gain and feed conversion. For fat thickness, the cold carcass weight $(\mathrm{kg})$, fat cover and weight gain $(\mathrm{kg})$ showed significant values. The shear force did not show significant differences between the genetic groups $(\mathrm{P}=0.0603)$.

Table 2. Means and standard deviations of the performance traits for the genetic groups.

\begin{tabular}{lccc}
\hline & & Genetic groups \\
\cline { 2 - 4 } Variables & $\mathrm{Si}$ & $1 / 2 \mathrm{D}-\mathrm{SI}$ & $1 / 2 \mathrm{WD}-\mathrm{SI}$ \\
\hline Hot carcass weight $(\mathrm{kg})$ & $11.58 \pm 1.79^{\mathrm{b}}$ & $13.49 \pm 2.44^{\mathrm{ab}}$ & $13.60 \pm 2.46^{\mathrm{a}}$ \\
Cold carcass weight $(\mathrm{kg})$ & $11.27 \pm 1.73$ & $13.17 \pm 2.43$ & $13.37 \pm 2.44$ \\
Fat cover & $2.42 \pm 0.51$ & $2.75 \pm 0.58$ & $2.75 \pm 0.40$ \\
Shear force $(\mathrm{kg})$ & $3.84 \pm 1.08$ & $3.33 \pm 0.68$ & $3.15 \pm 0.66$ \\
Average daily gain $(\mathrm{kg})$ & $0.24 \pm 0.054^{\mathrm{b}}$ & $0.31 \pm 0.058^{\mathrm{a}}$ & $0.32 \pm 0.076^{\mathrm{a}}$ \\
Feed conversion $(\mathrm{kg} / \mathrm{kg})$ & $4.14 \pm 0.16^{\mathrm{a}}$ & $3.52 \pm 0.45^{\mathrm{b}}$ & $3.65 \pm 0.67^{\mathrm{ab}}$ \\
Live weight at slaughter $(\mathrm{kg})$ & $24.05 \pm 2.95$ & $27.32 \pm 4.41$ \\
\hline Mean values followed by different letters indicate a difference by the Tukey test $(\mathrm{P}>0.05) .{ }^{1}$ Fat cover $=$ from 1.00 &
\end{tabular}

Table 3. Means and standard deviations for performance traits for abdominal fat thicknesses.

\begin{tabular}{lccc}
\hline & & Abdominal fat thickness \\
\cline { 2 - 4 } Variables & $2.0 \mathrm{~mm}$ & $2.5 \mathrm{~mm}$ & $3.0 \mathrm{~mm}$ \\
\hline Hot carcass weight $(\mathrm{kg})$ & $11.78 \pm 1.75$ & $12.66 \pm 2.13$ & $14.23 \pm 2.66$ \\
Cold carcass weight $(\mathrm{kg})$ & $11.53 \pm 1.75^{\mathrm{b}}$ & $12.34 \pm 2.04^{\mathrm{ab}}$ & $13.94 \pm 2.70^{\mathrm{a}}$ \\
Commercial yield of carcass $(\%)_{\text {Fat cover }^{1}}$ & $47.18 \pm 2.84$ & $47.48 \pm 1.95$ & $48.28 \pm 1.97$ \\
Shear force $\left.^{\mathrm{k} g}\right)$ & $2.37 \pm 0.43^{\mathrm{b}}$ & $2.58 \pm 0.36^{\mathrm{ab}}$ & $2.96 \pm 0.58^{\mathrm{a}}$ \\
\hline
\end{tabular}

Mean values followed by different letters indicate a difference by the Tukey test $(\mathrm{P}>0.05) .{ }^{1}$ Fat cover $=$ from 1.00 for very lean up to 5.00 for very fat. 
The results of the study of CAST and GDF-8 gene expression by qRT-PCR are presented in Table 4. Only GDF-8 gene expression differed between the different genetic groups; for genetic group vs abdominal fat thickness, the mRNA of the CAST gene was significant (Table 5). For GDF-8, the greatest expression was observed for the SI breed $(\mathrm{P}=0.0052)$ and for abdominal fat thickness of $3 \mathrm{~mm}(\mathrm{P}=0.0741)$.

$\begin{aligned} & \text { Table 4. Means and standard deviations of expression values of the mRNA (in arbitrary units) based on } \\
& \text { qRT-PCR analysis. }\end{aligned}$
\begin{tabular}{lcc}
\hline Breeds & \multicolumn{2}{c}{ Variables } \\
\cline { 2 - 3 } & CAST & GDF8 \\
\hline Santa Inês & $5.53 \pm 0.84$ & $8.73 \pm 1.60^{\mathrm{a}}$ \\
1/2 Dorper-Santa Inês & $3.96 \pm 1.65$ & $6.41 \pm 2.11^{\mathrm{b}}$ \\
1/2 White Dorper-Santa Inês & $4.95 \pm 1.25$ & $7.29 \pm 1.11^{\mathrm{ab}}$ \\
Fat thickness & $4.23 \pm 1.66$ & $6.82 \pm 1.58$ \\
$2 \mathrm{~mm}$ & $4.81 \pm 1.49$ & $7.25 \pm 2.25$ \\
$2.5 \mathrm{~mm}$ & $5.41 \pm 0.78$ & $8.36 \pm 1.50$ \\
\hline mm
\end{tabular}

Different letters in the columns present significant differences by the Tukey test $(\mathrm{P}<0.05)$. CAST $=$ calpastatin; GDF8 $=$ myostatin

Analysis of the interaction between the genetic groups and fat thicknesses (Table 5) revealed that the CAST gene had a higher expression in lambs of the SI breed when slaughtered with $2.5 \mathrm{~mm}$ fat thickness, where this breed was considered the one producing the least tender meat.

Table 5. Breakdown of interaction for the CAST gene, based on mRNA expression values (in arbitrary units).

\begin{tabular}{lcccc}
\hline Breeds & \multicolumn{3}{c}{ Abdominal fat thickness } \\
\cline { 2 - 5 } & $2.0 \mathrm{~mm}$ & $2.5 \mathrm{~mm}$ & $3.0 \mathrm{~mm}$ & Overall \\
\hline SI & $5.51^{\mathrm{aA}}$ & $5.95^{\mathrm{Aa}}$ & $5.14^{\mathrm{aA}}$ & 5.53 \\
$1 / 2 \mathrm{D}-\mathrm{SI}$ & $2.62^{\mathrm{bB}}$ & $3.42^{\mathrm{bB}}$ & $5.85^{\mathrm{aA}}$ & 4.16 \\
$1 / 2 \mathrm{WD}-\mathrm{SI}$ & $4.56^{\mathrm{aA}}$ & $5.06^{\mathrm{aAB}}$ & $5.23^{\mathrm{aA}}$ & \\
Overall & 4.23 & 5.01 & 5.41 & \\
\hline
\end{tabular}

Different upper case letters in the same column and different lower case letters on the same line indicate statistically significant differences by the Tukey test $(\mathrm{P}<0.005)$.

\section{DISCUSSION}

In general, considering the performance traits of the animals under study, the $1 / 2 \mathrm{WD}$ SI and $1 / 2$ D-SI lambs displayed higher levels than did the SI breed. The superior performance of the Dorper cross-breeds is due to this breed's higher resistance against periods of adverse conditions, such as heat, cold or limited food, maintaining good health and body condition (Marais et al., 1991). In studying the average daily weight gain in the Dorper breed, Burke et al. (2003) also observed better results when compared to other breeds.

In general, higher levels of calpastatin mRNA were found in the muscle samples obtained from the SI breed, that is, CAST gene expression in this genetic group was $39.65 \%$, higher than in the samples of $1 / 2 \mathrm{WD}$-SI and $25 \%$ greater than in the $1 / 2 \mathrm{D}$-SI samples.

From what is known about the action of calpastatin, higher gene expression in the 
muscle of Santa Inês breed animals leads to greater production of this enzyme and consequent calpain inhibition, resulting in less meat tenderness. This was confirmed by the shear force of the muscle samples in our study, which was greater for the SI breed $(P=0.0563)$, indicating that the meat was less tender in this breed in relation to the other genetic groups studied.

As reported by Hopkins et al. (2011), there is clear evidence of the effect of major genes on meat quality traits, such as tenderness and intramuscular fat. The calpastatin gene is heavily studied as it is considered a candidate gene and is associated with weight performance and carcass traits. The works of Lindholm-Perry et al. (2009) assessed the relations between single-nucleotide polymorphisms (SNPs) of this gene, with its expression and tenderness in the longissimus dorsi muscle in Duroc-Landrace-Yorkshire pigs. According to these authors, variation in shear force can be associated with three markers in the CAST gene, whose sequences in the GenBank are described by accession Nos. 41658_290i, 65565_349 and 65644_369, which show highly significant results. Significant differences in shear force between bovine breeds have also been reported by Morris et al. (2006), who also took into account polymorphisms in the calpastatin and calpain genes.

It was also observed that increased abdominal fat thickness coincided with increased expression of the CAST and GDF8 genes, which may have been related to the time required for each genetic group to attain the fat thickness established by the study, meaning that the animals remained in confinement for longer periods, thus increasing the animal age at slaughter, which could be directly associated with meat quality (Figure 1). Subcutaneous fat influences meat tenderness, where it causes a slower decline in temperature and $\mathrm{pH}$ during post-mortem cooling, which reduces the chance of cold shortening, but muscles can have different ideal fat quantities and any excess can be detrimental instead of beneficial to meat quality. This can explain the differences in the expression for the fat thickness trait, where the carcasses with $3 \mathrm{~mm}$ fat, as a rule, had high mRNA levels of the calpastatin gene for all the groups analyzed (Osório et al., 2009) (Table 4).

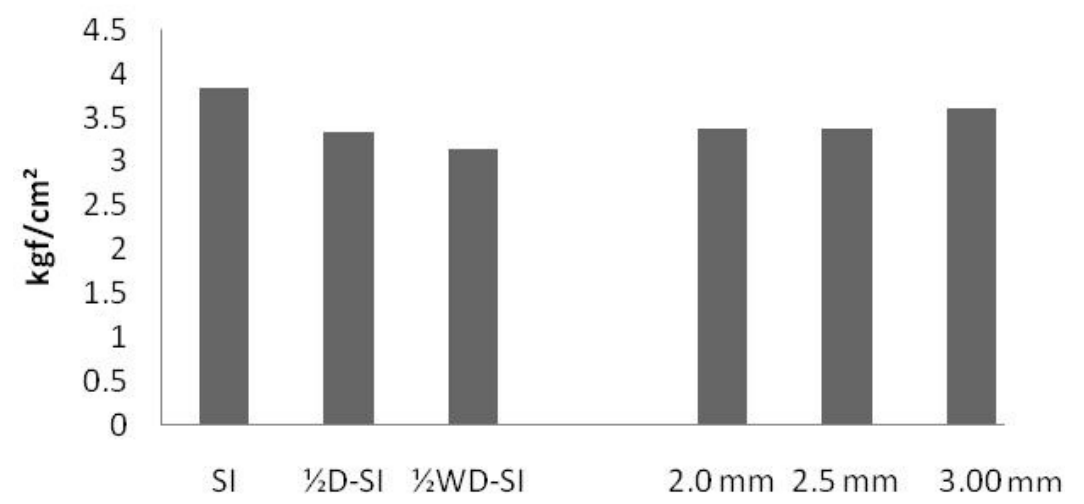

Figure 1. Graph of the shear force for the genetic groups and fat thickness. SI $=$ Santa Inês; $1 / 2 \mathrm{D}-\mathrm{SI}=1 / 2$ DorperSanta Inês; $1 / 2 \mathrm{WD}-\mathrm{SI}=1 / 2$ White Dorper-Santa Inês.

The myostatin gene is also responsible for influencing the meat tenderness phenotype. As well as being a gene that controls the proliferation of myoblasts and muscle fiber formation, its overexpression leads to muscular hyperplasia, which is closely related to calpastatin 
expression. The correlation of the two genes observed in this work was $0.79(\mathrm{P}<0.0001)$, considered a high correlation, which confirmed the expected results. McPherron and Lee (1997) suggested that myostatin negatively regulates skeletal muscle growth, limiting muscle size. Table 3 shows the mRNA expression values of this gene, in arbitrary units. The expression pattern is presented likewise for the CAST gene, confirming an association between the genes (Figure 2). The SI breed showed the highest expression values $(8.73 \pm 1.60)$, with the crossbreed $1 / 2$ D-SI displaying the lowest value.

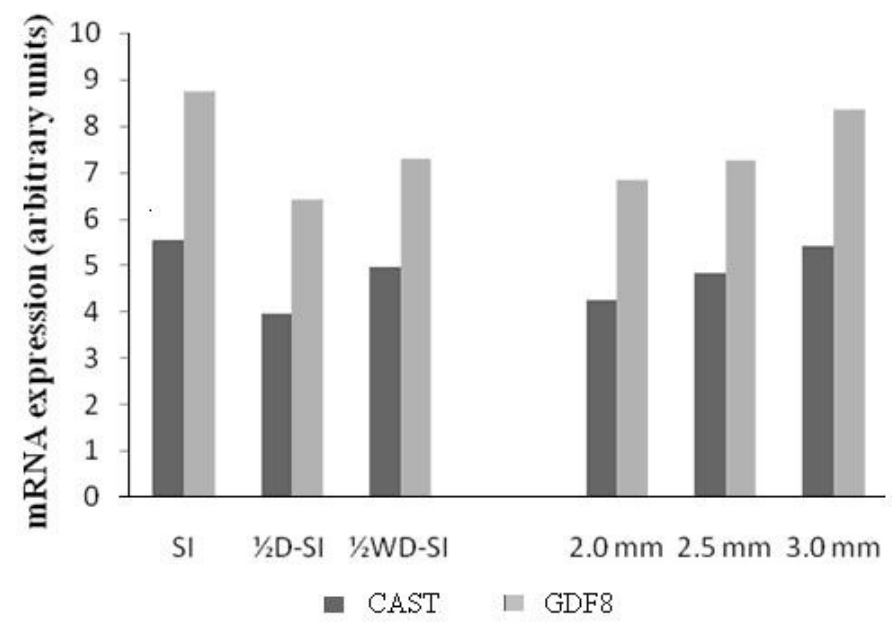

Figure 2. Graph of the mRNA expression values (in arbitrary units) obtained for the CAST and GDF8 genes for the genetic groups and fat thicknesses. CAST $=$ calpastatin gene; GDF8 = myostatin gene.

Overexpression of GDF8 leads to a higher percentage of fat deposition, through its direct action in adipogenesis (Guizoni et al., 2010). In arbitrary units of mRNA, the results of 8.36 for $3.0 \mathrm{~mm}$ fat thickness, 7.25 for $2.5 \mathrm{~mm}$ and 6.82 for $2.0 \mathrm{~mm}$ may count in favor of the action of this gene in adipogenesis $(\mathrm{P}=0.0798)$. For the fat thickness trait, the results revealed the highest myostatin expression for $3.0 \mathrm{~mm}$, but this result was not significant.

The SI breed showed the least muscular development, characterized by lower weight performance results and carcass traits and a higher shear force $(\mathrm{P}=0.0563)$. Therefore, the higher expression of genes that encode calpastatin and myostatin in the muscles of this breed of animal is indicative of a lower meat tenderness phenotype, regardless of fat thickness.

The lowest expression of the calpastatin and myostatin genes for the $1 / 2 \mathrm{D}$-SI crossbreed indicates that this group has better performance for the meat tenderness phenotype when slaughtered with 2.0 or $2.5 \mathrm{~mm}$ fat thickness.

\section{ACKNOWLEDGMENTS}

The authors are grateful to Procad-CAPES and CNPq.

\section{REFERENCES}

Asghar A and Pearson AM (1980). Influence of ante and post mortem treatments upon muscle composition and meat 
quality. Adv. Food Res. 26: 53-213.

Burke JM, Apple JK, Roberts WJ, Boger CB, et al. (2003). Effect of breed-type on performance and carcass traits of intensively managed hair sheep. Meat. Sci. 63: 309-315.

Ciéslak D, Blicharski T, Kapelanski W and Pierzchala M (2003). Investigation of polymorphisms in the porcine myostatin (GDF8; MSTN) gene. Czech J. Anim. Sci. 48: 69-75.

Du R, An XR, Chen YF and Qin J (2007). Functional analysis of the Myostatin gene promoter in sheep. Sci. China Series C Life Sci. 50: 648-654.

Guizoni DM, Lima ARR, Martinez PF, Damatto RL, et al. (2010). Miostatina e redução da massa muscular em doenças crônicas. Rev. Bras. Clin. Med. 8: 266-271.

Hopkins DL and Thompson JM (2002). Factors contributing to proteolysis and disruption of myofibrillar proteins and the impact on tenderisation in beef and sheep meat. Aust. J. Agric. Res. 53: 149-166.

Hopkins DL, Fogarty NM and Mortimer SI (2011). Genetic related effects on sheep meat quality. Small Ruminant Res. 101: 160-172.

Lee SJ and McPherron AC (2001). Regulation of myostatin activity and muscle growth. Proc. Nat. Acad. Sci. 98: 93069311.

Lindholm-Perry AK, Rohrer GA, Holl JW, Shackelford SD, et al. (2009). Relationships among calpastatin single nucleotide polymorphisms, calpastatin expression and tenderness in pork longissimus. Anim. Genet. 40: 713-721.

Marais PG, van der Merwe HJ and du Toit JEJ (1991). The efficiency of protein and fat deposition during growth in Dorper sheep. South Afr. Soc. Anim. Sci. 21: 103-107.

McPherron AC and Lee SJ (1997). Double muscling in cattle due to mutations in the myostatin gene. Proc. Natl. Acad. Sci. U. S. A. 94: 12457-12461.

Moody WG, Tichenor DA, Kemp JD and Fox JD (1970). Effects of weight, castration and rate of gain on muscle fiber and fat cell diameter in two ovine muscles. J. Anim. Sci. 31: 676-680.

Morgan JB, Wheeler TL, Koohmaraie M, Savell JW, et al. (1993). Meat tenderness and the calpain proteolytic system in longissimus muscle of young bulls and steers. J. Anim. Sci. 71: 1471-1476.

Morris CA, Cullen NG, Hickey SM, Dobbie PM, et al. (2006). Genotypic effects of calpain 1 and calpastatin on the tenderness of cooked M. longissimus dorsi steaks from Jersey x Limousin, Angus and Hereford-cross cattle. Anim. Genet. 37: 411-414.

National Research Council (2007). Nutrient Requirements of Small Ruminants. 1th ed. National Academy Press, Washington.

Osório JCS, Osório MTM and Sañudo C (2009). Características sensoriais da carne ovina. Rev. Bras. Zootec. 38: 292-300.

Rubensam JM, Felício PE and Termignoni C (1998). Influência do genótipo Bos indicus na atividade de calpastatina e na textura da carne de novilhos abatidos no sul do Brasil. Ciênc. Tecnol. Alimentos 18: 405-409.

Soria LA and Corva PM (2004). Factores genéticos y ambientales que determinan la terneza de la carne bovina. Arch. Latinoam. Prod. Anim. 12: 73-88.

Volpelli LA, Failla S, Sepileri A and Piasentier E (2004). Calpain system in vitro activy and miofibrial fragmentation index, in fallow deer effects of age and supplementation. Meat Sci. 69: 579-582. 